Nova Southeastern University

Florida

NOVA SOUTHEASTERN

UNIVERSTYY

NSUWorks

Marine \& Environmental Sciences Faculty Articles Department of Marine and Environmental Sciences

$1-1-1987$

\title{
The Indo-Pacific Audulla chelifera Reported from the Caribbean Sea (Crustacea: Amphipoda)
}

James Darwin Thomas

thomasjd@nova.edu

J.L. Barnard

Smithsonian Institution

Find out more information about Nova Southeastern University and the Halmos College of Natural Sciences and Oceanography.

Follow this and additional works at: https://nsuworks.nova.edu/occ_facarticles

Part of the Marine Biology Commons, and the Oceanography and Atmospheric Sciences and Meteorology Commons

\section{NSUWorks Citation}

James Darwin Thomas and J. L. Barnard. 1987. The Indo-Pacific Audulla chelifera Reported from the Caribbean Sea (Crustacea: Amphipoda) .Proceedings of the Biological Society of Washington, (2) : 364 -370. https://nsuworks.nova.edu/occ_facarticles/602.

This Article is brought to you for free and open access by the Department of Marine and Environmental Sciences at NSUWorks. It has been accepted for inclusion in Marine \& Environmental Sciences Faculty Articles by an authorized administrator of NSUWorks. For more information, please contact nsuworks@nova.edu. 


\section{THE INDO-PACIFIC AUDULLA CHELIFERA REPORTED FROM THE CARIBBEAN SEA (CRUSTACEA: AMPHIPODA)}

\section{J. D. Thomas and J. L. Barnard}

Abstract.-Audulla chelifera Chevreux is reported for the first time outside of the Indian Ocean and Red Sea. It has now been found in the western Caribbean inhabiting the alga Turbinaria turbinata (Linneaus) Kuntze in backreef regions of the Belize barrier reef.

Audulla Chevreux (1901) was merged with Gammaropsis Liljeborg by J. L. Barnard (1973), who treated Audulla and several other genera as subgenera of Gammaropsis. Audulla chelifera was described from La Digue, Seychelles Islands (Indian Ocean) from marine algae but has never been reported since. A similar morph has now been found in great abundance from the alga Turbinaria turbinata L. at Curlew Cay, Belize, in the Caribbean Sea. Any distinctions between Belize specimens and the fine description of Chevreux (1901) are so miniscule that $\mathrm{Ca}$ ribbean specimens are identifiable as $A$. chelifera.

\section{Legends}

Capital letters denote main parts in the following list; lower case letters to right of capital letters or in body of figure indicate modifications as follows; lower case letters to left of capital letters indicate specimens described in captions: A, antenna; B, body; $\mathrm{D}$, dactyl; $\mathrm{G}$, gnathopod; I, inner plate or ramus; $\mathrm{L}$, labium; $\mathrm{M}$, mandible; $\mathrm{P}$, pereopod; R, uropod; S, maxilliped; T, telson; V, palp; W, pleon; $\mathrm{X}$, maxilla.

\section{Family Isaeidae Audulla Chevreux}

Audulla Chevreux, 1901:431 (Audulla chelifera Chevreux, 1901, type species by monotypy).

Diagnosis. - Article 3 of antenna 1 as long as article 1 ; accessory flagellum multiarticu- late; flagellum of male antenna 2 flattened, expanded, almost paddle-shaped; head deeply recessed behind eye for reception of antenna 2; mandibular palp stout, article 3 clavate; inner plate of maxilla 1 setose medially; inner plate of maxilla 2 with oblique mediofacial row of setae; dactyl of maxilliped stubby, multispino-setose; coxae ordinary to short, contiguous, coxa 2 largest, followed in order by coxae $3,4,5,1,6,7$; gnathopod 1 small in both sexes, ordinary; gnathopod 2 of both sexes slightly (female) to greatly (male) enlarged, in male carpus short and lobate, propodus immense, rectangular, chelate, thumb short and blunt, dactyl overlapping palm, with inner hump fitting slight palmer excavation; uropod 3 small but relative to its size peduncle weakly elongate, rami subequal, scarcely longer than peduncle, multispino-setose apically; telson fleshy, entire.

Relationship.-Audulla differs from the various genera placed in the supergenus Gammaropsis by J. L. Barnard (1973) in the expanded flagellum of male antenna 2, and the chelate male gnathopod 2. The diversity in size of anterior coxae is found in many other taxa of the Gammaropsis group and therefore has little taxonomic value.

\section{Audulla chelifera Chevreux} Figs. 1-4

Audulla chelifera Chevreux, 1901:432-436, figs. 56-65.-Ledoyer, 1982:222, fig. 80. Eurystheus lina Kunkel, 1910:81, fig. 31. Eurystheus semichelatus K. H. Barnard, 1957:809, fig. 5. 


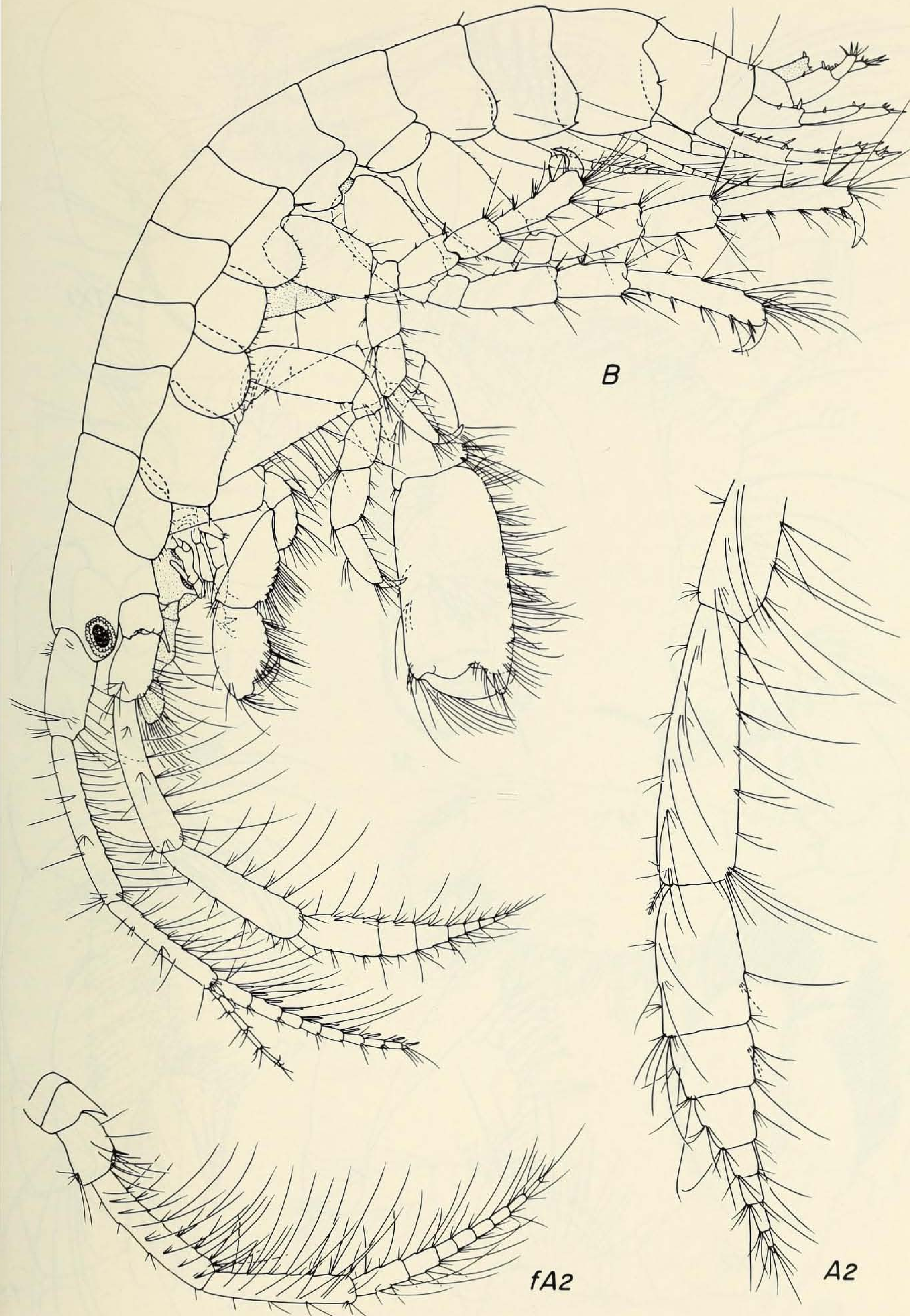

Fig. 1. Audulla chelifera male "e," $4.65 \mathrm{~mm}$; f = female "f," $4.03 \mathrm{~mm}$. 

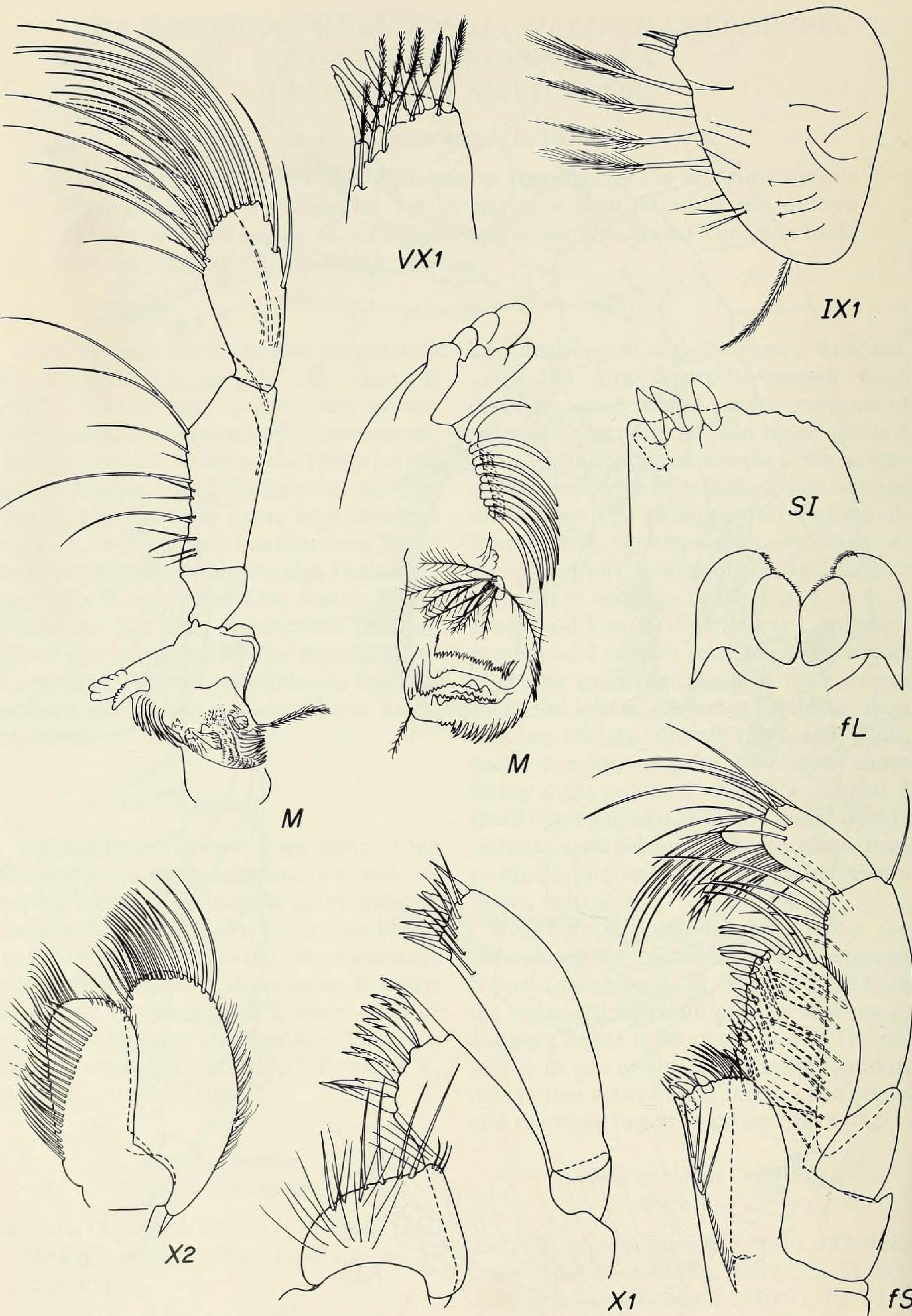

$f L$
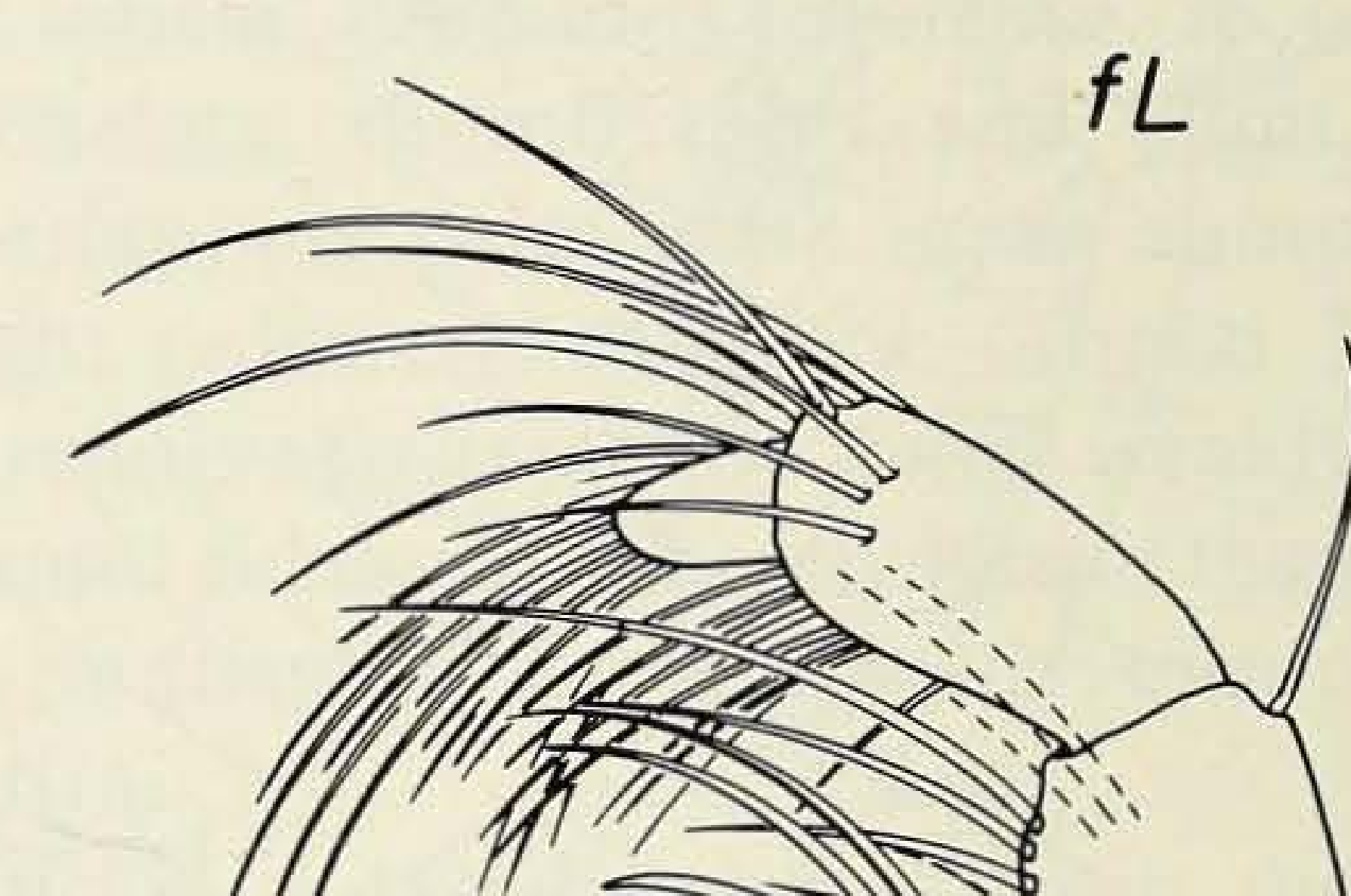
$x_{1}$

Fig. 2. Audulla chelifera male "e," $4.65 \mathrm{~mm} ; \mathrm{f}=$ female "f," $4.03 \mathrm{~mm}$. 


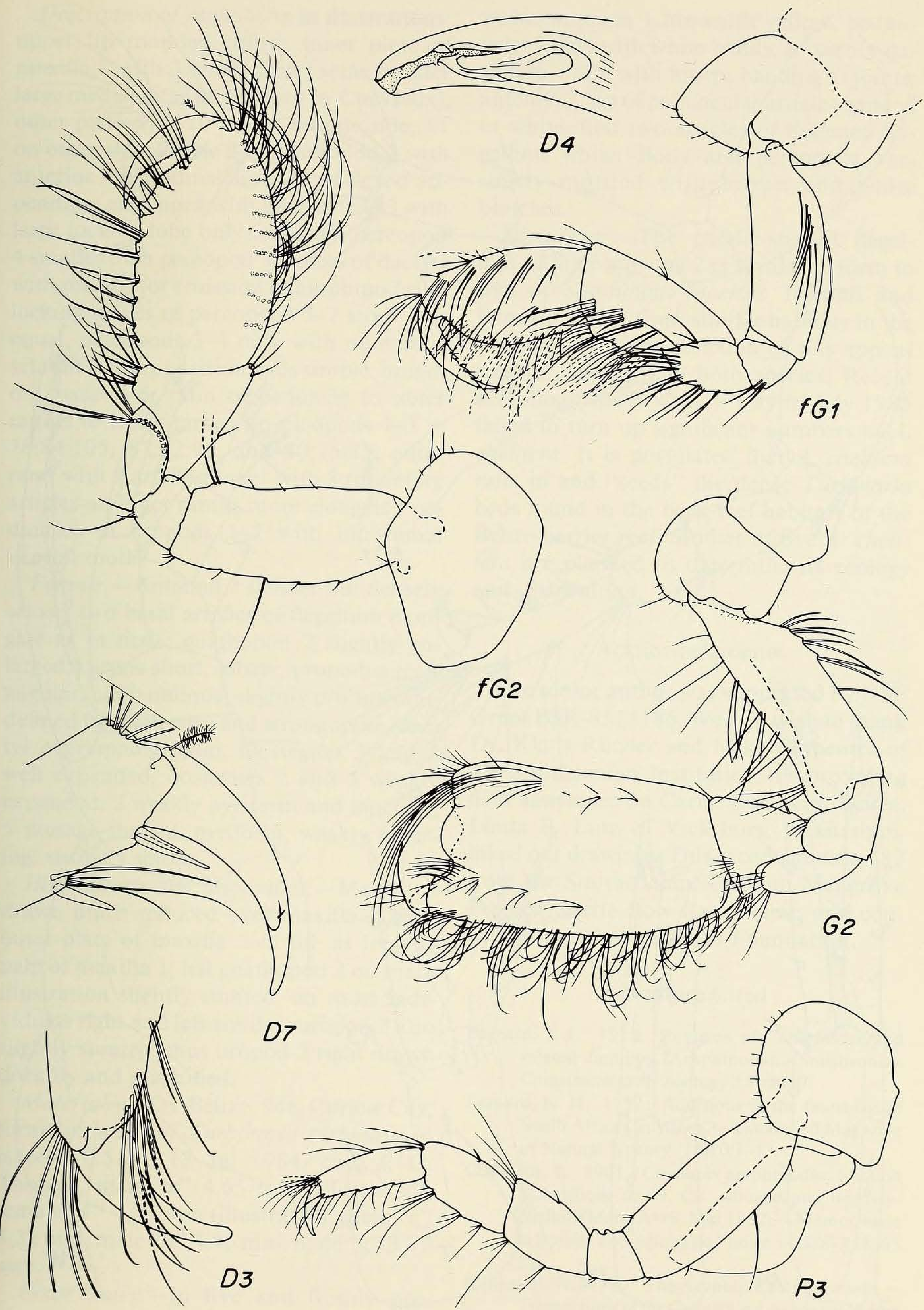

Fig. 3. Audulla chelifera male "e," $4.65 \mathrm{~mm}$; = female "f," $4.03 \mathrm{~mm}$. 


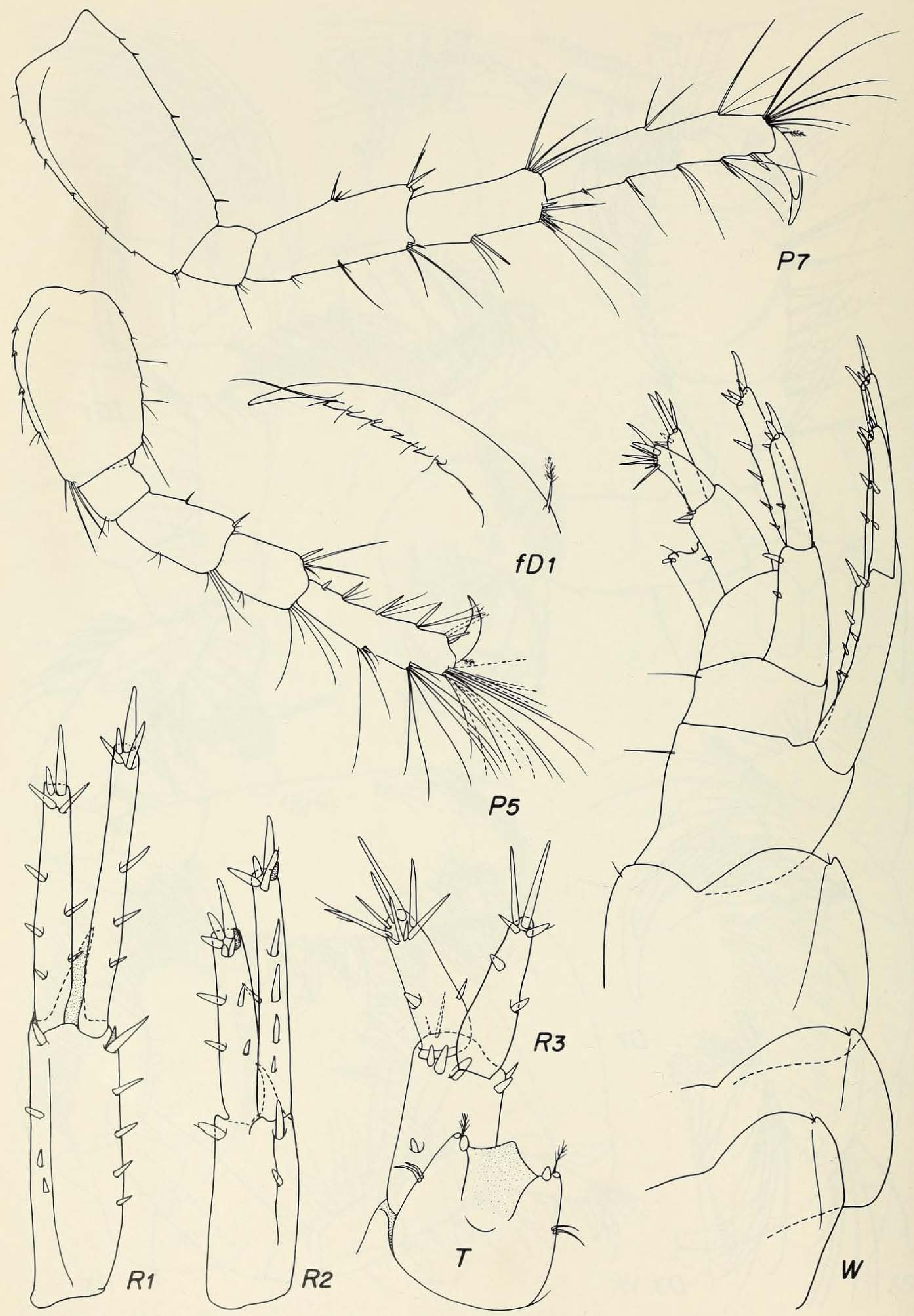

Fig. 4. Audulla chelifera male "e," $4.65 \mathrm{~mm}$; = female "f," $4.03 \mathrm{~mm}$. 
Description of male. - As in illustrations; upper lip rounded below; inner plate of maxilla 1 with 3 small apical setae besides large medial setae (not shown by Chevreux), outer plate with 10 spines on one side, 11 on other side; article 2 of gnathopod 2 with anterior longitudinal sinus to fit flexed appendage, each apex with lobe, article 3 with large locking lobe only medially; pereopod 4 smaller than pereopod 3 , apices of dactyls with meatus for emission of amphipod silk; locking spines of pereopods 5-7 stout, unequal, pereopods 3-4 only with numerous setae at locking position; gills simple, broad, on coxae 2-6; ratio of peduncle to outer ramus to inner ramus on pleopods $1-3=$ $78: 84: 105,87: 82: 95$, and 80:75:85, outer rami with 9 articles, inner with 8 (therefore articles on inner ramus more elongate); peduncles of uropods 1-2 with interramal ventral tooth.

Female.-Antenna 2 slender but densely setose, two basal articles of flagellum elongate as in male; gnathopod 2 slightly enlarged, carpus short, lobate, propodus rectangular, palm oblique, slightly protuberant, defined by weak cusp and strong spine, dactyl overlapping palm. Oostegites 3 and 4 well expanded, oostegites 2 and 5 weakly expanded, 2 weakly pyriform and tapering, 5 sausage-shaped, pyriform, weakly tapering, strongly setose.

Illustrations and anomalies. -Maxilla 2 drawn much reduced over maxilla 1 , thus outer plate of maxilla 2 in life as long as palp of maxilla 1; left gnathopod 2 on main illustration slightly stunted, on most individuals right and left similar; uropod 2 also slightly stunted, thus uropod 2 right drawn dorsally and magnified.

Material. -JDT Belize, 94a, Curlew Cay, formalin wash of Turbinaria turbinata in

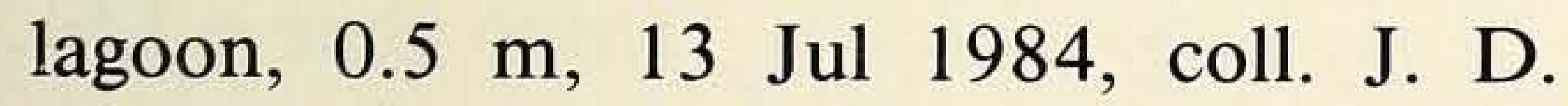
Thomas, male " $\mathrm{e}$ " $4.65 \mathrm{~mm}$ (illustrated), female "f" $4.03 \mathrm{~mm}$ (illustrated), male "c" $4.32 \mathrm{~mm}$, male "d" $4.46 \mathrm{~mm}$, male " $\mathrm{g}$ " 3.77 $\mathrm{mm}$.

Color notes. - In live and freshly preserved material: body generally translucent white; antenna 1 brownish yellow, peduncular joints with white bands; accessory flagellum white with brown banding at joints; antenna 2, tip of peduncular articles banded in white, first two articles of flattened flagellum white. Body and pereopods variously mottled with brown and white blotches.

Discussion. - The paddle-shaped flagellum of male antenna 2 is similar in form to that of Spathiopus looensis Thomas and Barnard, 1985, from similar habitats in the Florida Keys. The function of this appendage is unknown in both species. Recent sampling trips to Curlew Cay in July 1985 failed to turn up significant numbers of $A$. chelifera. It is postulated that $A$. chelifera rafts in and "seeds" the dense Turbinaria beds found in the back-reef habitats of the Belize barrier reef. Studies of live $A$. chelifera are planned to determine its ecology and distribution.

\section{Acknowledgments}

The senior author was supported by NSF Grant BSR-8515186. We also wish to thank Dr. Klaus Rützler and Mike Carpenter of the Smithsonian Institution for providing field assistance on Carrie Bow Key, Belize. Linda B. Lutz of Vicksburg, Mississippi, inked our drawings. This is contribution 182 from the Smithsonian Reef and Mangrove Project, Carrie Bow Cay, Belize, and contribution 187 of the Reef Foundation.

\section{Literature Cited}

Barnard, J. L. 1973. Revision of Corophiidae and related families (Amphipoda).-Smithsonian Contributions to Zoology 151:1-27.

Barnard, K. H. 1957. Additions to the fauna-list of South Africa Crustacea. - Annals and Magazine of Natural History (12)10:1-12.

Chevreux, E. 1901. Crustacés amphipodes: Mission Scientifique de M. Ch. Alluaud aux Îles Seychelles, (Mars, Avril, Mai 1892). - Mémoires de la Société Zoologique de France 14:388-438, 65 figs.

Kunkel, B. W. 1910. The Amphipoda of Bermuda.Transactions of the Connecticut Academy of Arts and Sciences 16:1-116, 43 figs. 
Ledoyer, M. 1982. Crustacés amphipodes gammariens. Familles des Acanthonotozomatidae à Gammaridae. - Faune de Madagascar 59:1-598.

Thomas, J. D., and J. L. Barnard. 1985. Two new species of two new gammaridan genera (Crustacea: Amphipoda) from the Florida Keys.Proceedings of the Biological Society of Washington 98:191-203, 6 figs.
(JDT) P.O. Box 120, Big Pine Key, Florida 33043; (JLB) Division of Crustacea, NHB-163, Smithsonian Institution, Washington, D.C. 20560, U.S.A. 